\title{
Tillage and Nitrogen Fertilization Impact on Irrigated Corn Yields, and Soil Chemical and Physical Properties Under Semi- arid Climate
}

\author{
Muhammad Iqbal', Abdul Ghaffar Khan ${ }^{1 *}$, Anwar-ul-Hassan', and K.R. Islam² \\ ${ }^{1}$ Institute of Soil \& Environmental Sciences, University of Agriculture, Faisalabad, Pakistan; ${ }^{2}$ Ohio State Univer- \\ sity South Centers at Piketon, Ohio, USA. * Mr. Khan is currently visiting the Watershed Hydrology Laboratory, \\ College of Tropical Agriculture and Human Resources, University of Hawaii-Manoa, Honolulu Hawaii, USA
}

Received: October 18, 2012 / Accepted: January 21, 2013

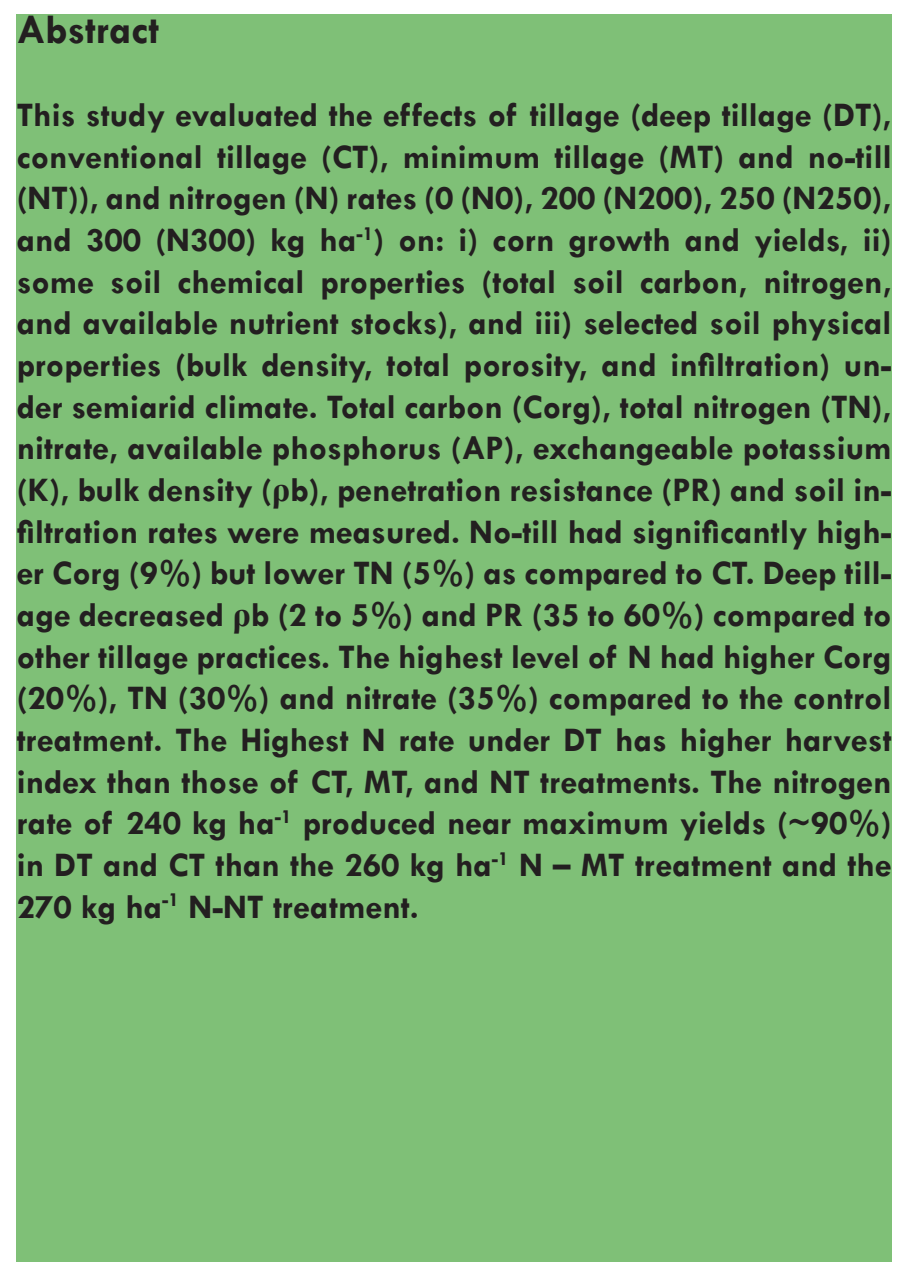

* Corresponding author: ghaffarniazi@gmail.com

\section{Introduction}

Agricultural sustainability depends on soil quality. While conventional tillage and frequent use of chemical fertilizers and pesticides increased crop yields and enhanced food security, conventional management practices have affected soil quality as well as productivity (McGarry et al., 2000, Islam and Weil, 2000, Sundermeier et al., 2011 ). Tillage operations and fertility management often influence soil properties, nutrient availability, and crop yields. Tillage is one of the important factors that influence soil properties and crop yields (Bennie and Botha, 1986; Islam and Weil 2000; Khurshid et al., 2006). Khurshid et al. (2006) reported that tillage contributes up to $20 \%$ of the crop production factors. The type and intensity of tillage affects the agricultural sustainability through its influence on soil properties (McGarry et al., 2000; Sundermeier et al., 2011). While CT decreases soil compaction, provides favorable seed bed preparation, enhances root growth and development, controls weeds, and maintains crop yields (Bennie and Botha, 1986; Varsa et al., 1997), frequent plowing is responsible for soil structural degradation, accelerated erosion, loss of soil organic matter (SOM), and disruption in air, water and nutrient cycles (Sundermeier et al., 2011 ). Moreover, tillage pans (e.g. plow pan a 15 to $20 \mathrm{~cm}$ depth) resulting from the frequent use of tillage tools often led to crop yield reductions.

Conservation tillage practices such as no-tillage or minimum tillage that allow crop residues deposition on the soil surface have resulted in accumulation of soil organic matter (SOM), improved aggregate stability and water infiltration, and increased biological efficiency (Liebig et al., 2004; Sundermeier 
et al., 2011). However, surface compaction resulting from the use of agricultural machineries and greater immobilization of nitrogen $(\mathrm{N})$ from surface accumulation of crop residues under transitional NT or MT are associated with crop yield reductions. Several studies suggested using sub-soiling or deep tillage to break-down surface and shallow tillage pans and improve soil water-air systems, reduce compaction, and increase root growth and crop yields (Bennie and Botha, 1986; Varsa et al., 1997; Pikul and Arase, 1999). It is reported that soils under NT had greater bulk density than those soils under CT and mould-board plowing (Salinas-Garcia et al., 1997). However, Sundermeier et al. (2011) reported that long-term continuous NT (44+ years) had lower or similar bulk density comparable to CT. Improved soil physical conditions is one of the components of soil quality management for economic crop production.

Nitrogen fertilization plays a significant role in improving soil fertility and increasing crop productivity (Habtegebrial et al., 2007). It is reported that $\mathrm{N}$ fertilization increased grain yield by 43 to $68 \%$ and biomass production by 25 to $42 \%$ (Ogola et al., 2002). Moreover, $\mathrm{N}$ fertilization contributes to increase (18 to $34 \%$ ) soil residual $N$ contents (Yang et al., 2007). Several factors including tillage intensity, crop rotation, and irrigation often influenced soil $\mathrm{N}$ cycling. While transitional NT reportedly immobilizes $\mathrm{N}$ and subsequently, affects crop yields, CT accelerated SOM decomposition and mineralization of nutrients especially $N$. The objectives of the study were to evaluate the effects of tillage and $\mathrm{N}$ fertilization on: i) corn growth and yields, ii) soil chemical properties (total soil carbon, nitrogen, and available nutrient stocks), and iii) some soil physical properties (bulk density, total porosity, and infiltration) under semiarid climate.

\section{Materials and Methods}

\section{Study Site and Experimental Treatments}

The study was conducted at the research farm (latitude $31^{\circ} 26^{\prime} \mathrm{N}$ and $73^{\circ} 06^{\prime} \mathrm{E}$, altitude $185 \mathrm{~m}$ above mean sea level) of the Institute of Soil and Environmental Sciences, University of Agriculture, Faisalabad, Pakistan in 2007 and 2008. Soil is a well-drained Hafizabad sandy clay loam (mixed, semi-active, isohyperthermic typic Calciargids). Selected chemical and physi-

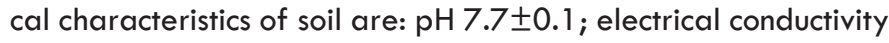
(Ec) $2.82 \pm 0.3 \mathrm{dS} \mathrm{m}^{-1}$; sand $52.8 \%$; silt $19.7 \%$; and clay $27.5 \%$. The climate of the region is subtropical semi-arid with an annual average rainfall of $490 \mathrm{~mm}$ and more than $70 \%$ of the rainfall occurs during June-September. Mean monthly minimum temperature is $13^{\circ} \mathrm{C}$ in January and maximum temperature is $45^{\circ} \mathrm{C}$ in July. Major crops are irrigated corn, wheat, cotton, sugarcane, rice, fodder, and pulses.

A randomized complete block design with four tillage systems (DT, CT, MT, NT) and four $\mathrm{N}$ levels at $0,200,250$ and $300\left(\mathrm{~N}_{0^{\prime}}\right.$ $\mathrm{N}_{200}, \mathrm{~N}_{250}$, and $\mathrm{N}_{300}$, respectively) $\mathrm{kg} \mathrm{ha}^{-1}$, respectively in a splitplot combination was established. Tillage was used as a main plot and $\mathrm{N}$ level as a subplot. Each treatment was replicated three times in $5.5 \mathrm{~m} \mathrm{X} 10 \mathrm{~m}$ plots. In NT treatments, herbicides were used to control weeds whereas in MT, the field operations comprised of two plowing and two planking operations. Conven- tional tillage consists of one disk plowing, four cultivations, and two planking. Hoeing along with herbicides was used to control weeds in CT. In DT, the field operation comprised two 30 to 40 $\mathrm{cm}$ deep chiseling with three shovels spaced at $45 \mathrm{~cm}$ apart followed by four narrow tine cultivations and two planking with a wooden plank. Chiseling was done annually.

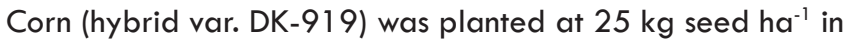
July and the planting was done manually using dibble with $70 \mathrm{~cm}$ spacing between rows and $20 \mathrm{~cm}$ between plants. Recommended doses of phosphorus (P) and potassium (K) (150-105 $\mathrm{kg} \mathrm{ha}^{-1}$ ) were applied as triple super-phosphate and sulfate of potash at time of planting, while $\mathrm{N}$ as urea was applied in three splits. One third of each $\mathrm{N}$ level was applied at planting and seedbed preparation, one month after germination, and at tussling stage. Atrazine (2-chloro-4-(ethylamino)-6-(isopropylamino)-striazine), a pre-/post-emergence broadleaf weed control herbicides, at $1250 \mathrm{ml} \mathrm{ha}^{-1}$ was applied to control weeds. Agronomic parameters including plant height, 1000-grains weight, and grain and total yields were recorded.

\section{Soil Collection and Analysis}

Soil samples at $10 \mathrm{~cm}$ intervals from the top $40 \mathrm{~cm}$ depth were collected randomly before planting and immediately after crop harvest from six different locations in each replicated plot and mixed to obtain a composite sample. Field-moist samples were analyzed for nitrate, available phosphorus, and exchangeable potassium. A portion of the soil samples were air-dried at room temperature $\left(\sim 25^{\circ} \mathrm{C}\right)$ and ground to pass a $2 \mathrm{~mm}$ sieve before analyzing for $\mathrm{C}_{\text {org }}$ and $\mathrm{TN}, \mathrm{pH}, \mathrm{EC}$, and sand, silt, and clay contents. The $\mathrm{C}_{\text {org }}$ was determined by following the WalkeyBlack standard wet oxidation method; soil $\mathrm{pH}$ was measured by a glass electrode $\mathrm{pH}$ meter; soil EC was determined by a conductivity meter; nitrate concentration following the method detailed by Sims and Jackson (1971); available P by the standard ascorbic acid method; K by flame photometry; particle size analysis by the standard hydrometer method; bulk density by standard core method; water infiltration with double ring infiltrometer; and soil strength with a cone penetrometer;

The stocks of $\mathrm{C}_{\text {org }}, \mathrm{TN}$, nitrate, $\mathrm{AP}$, and $\mathrm{K}$ were calculated by multiplying their concentrations with the sampling depth and $\rho b$. All the results were expressed on the basis of oven-dried ( 1050C) weight of soil.

\section{Statistical Analysis}

Data were analyzed in a split-plot arrangement of randomized complete block design using the analysis of variance procedure of SAS v. 9.13 (SAS Institute, 2008) with tillage as a main plot and nitrogen as a sub-plot. The blocks, tillage $x$ blocks and nitrogen $x$ blocks were considered as random effects, and the tillage, nitrogen soil depth and their interaction were considered as fixed effects. Significant differences in soil chemical and physical properties attributed to the effects of main-plot, subplot, block, and their interactions were evaluated by the least significant difference (LSD) test. Means were separated with a probability level of $<0.05$ unless otherwise mentioned. Relative 
yield of corn was regressed on $\mathrm{N}$ levels using boundary line technique (Webb, 1972) to calculate optimum $N$ fertilization under different tillage systems for achieving at-least $95 \%$ of irrigated corn yields.

\section{Results and Discussion}

\section{Bulk Density, Soil Strength, and Water Infiltration}

Tillage and $\mathrm{N}$ fertilization had significant effect on $\rho b$, soil strength, and water infiltration characteristics without an interaction (Fig. 1 to 4 ). Deep tillage results in 4 to $9 \%$ decrease in pb compared to CT, MT and NT, respectively (Fig. 1). However, the decrease of $\rho b$ values as a result of tillage was most visible for the top 20-cm depth. Soil strength was highest in NT, intermediate in MT and CT, and lowest in DT. On average, the NT had 63\% higher soil strength than DT (Fig. 3). DT had 53\% higher infiltration rates than that of NT (Fig. 4). Similarly, bulk density was reduced by 1 to $9 \%$ in $\mathrm{N}_{200}, \mathrm{~N}_{250}$ and $\mathrm{N}_{300}$ treatments compared to control (Fig. 2). However, soil strength was 2 to $3 \%$ higher in the control treatment compared to $\mathrm{N}_{200}, \mathrm{~N}_{250^{\prime}}$ and $\mathrm{N}_{300}$ treatments, respectively. Mean water infiltration rates

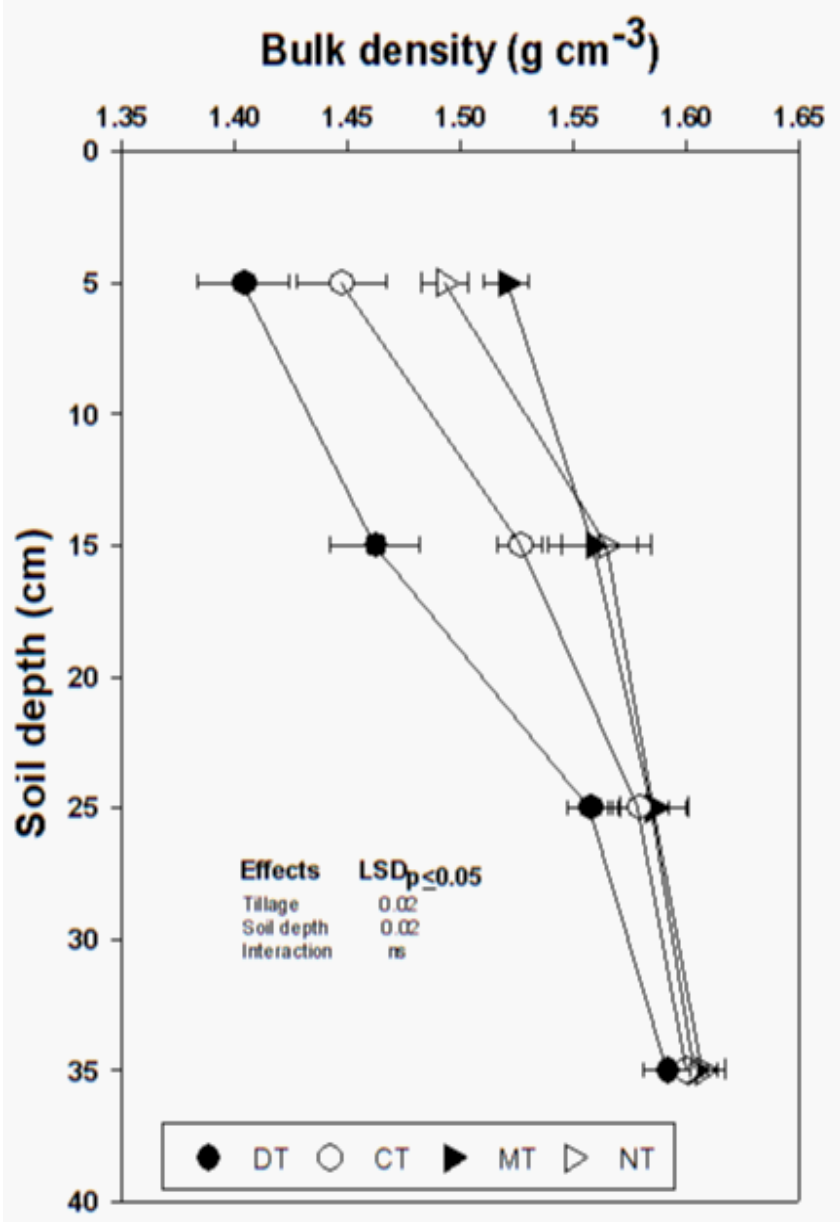

Figure 1. Tillage effects on bulk density at different depths of soil. were higher in the treatments with higher levels of $\mathrm{N}$ fertilization. Irrespective of tillage or $\mathrm{N}$ treatments, $\rho b$ increased with increasing soil depth.

Significantly higher $\rho b$ values measured in transitional NT followed by MT are due to the absence of tillage operations and compaction caused by agricultural machinery and natural processes (Unger and Jones, 1998; Khurshid et al., 2006). In contrast, tillage resulted a mixing of soil and temporarily increased total soil porosity leading to minimum soil strength. The effects of tillage especially DT in reducing $\rho b$ was attributed to an increase in porosity and water infiltration but decrease in soil strength. In other words, decreased $\rho b$ and soil strength associated with higher water infiltration rates. The lower soil strength with DT was likely the result of tillage-induced soil loosening caused by deeper penetration of tillage implements. These results are similar to Lampurlanes and Cantero-Martinez (2003) who reported higher soil strengths in NT than in sub-soiling and MT. These results are in agreement with those of Ishaq et al. (2002). Highest water infiltration rates in DT than in NT are due to greater soil porosity and the breaking-up of hard pan to improve water movement within soil profile (Ishaq et al., 2002; Lampurlanes and Cantero-Martinez, 2003). Moreover, the DT

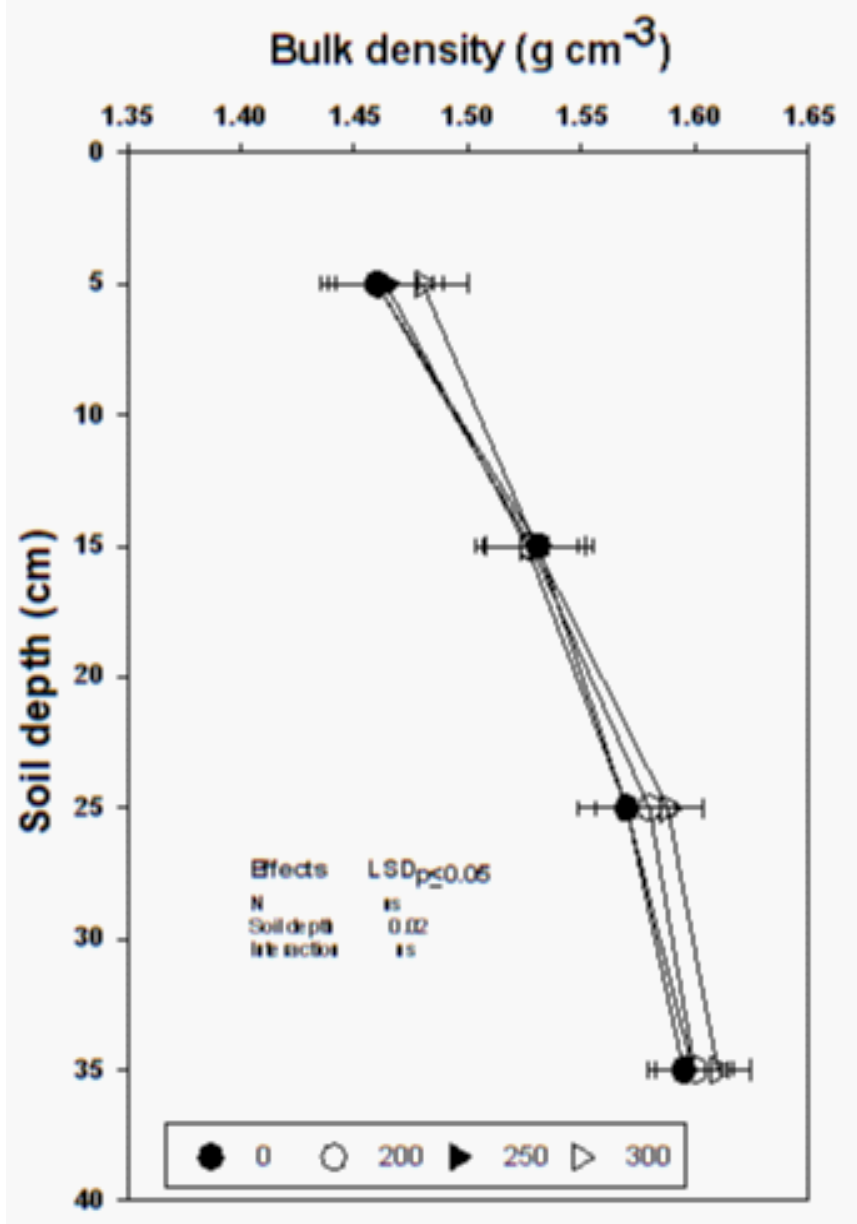

Figure 2. Nitrogen fertilization effects on bulk density at different depths of soil. 
Table 1. Tillage and nitrogen treatments interaction on total carbon, total nitrogen, nitrate, available phosphorus and exchangeable potassium concentration and soil bulk density under irrigated corn.

\begin{tabular}{|c|c|c|c|c|c|c|c|}
\hline \multicolumn{2}{|l|}{$\begin{array}{l}\text { Treatment } \\
\text { Combinations }\end{array}$} & $\mathrm{C}_{\text {org }}$ & $\mathrm{TN}$ & $\mathrm{NO}_{3}$ & $\begin{array}{c}\mathrm{AP} \\
\mathrm{mg} \mathrm{kg}^{-1}\end{array}$ & $\mathrm{~K}$ & $\begin{array}{l}\rho b \\
\mathrm{~g} \mathrm{~cm}^{-3}\end{array}$ \\
\hline \multicolumn{8}{|l|}{ Main plot: Tillage } \\
\hline NT & & $3.7 a^{\S}$ & $0.39 \mathrm{~b}$ & $35 b$ & $12 a$ & $110 a$ & 1.560 \\
\hline MT & & $3.6 a$ & $0.39 \mathrm{~b}$ & $39 b$ & $12 a$ & $109 a$ & $1.57 a$ \\
\hline $\mathrm{CT}$ & & $3.4 \mathrm{~b}$ & $0.40 a b$ & $38 b$ & $13 a$ & $110 a$ & $1.54 \mathrm{~b}$ \\
\hline DT & & $3.5 a b$ & $0.41 \mathrm{a}$ & $46 a$ & $13 a$ & $107 a$ & $1.50 c$ \\
\hline \multicolumn{8}{|c|}{ Sub-plot: Nitrogen (N@kg ha-1) } \\
\hline NO & & $3.2 \mathrm{~d} \varphi$ & $0.32 d$ & $29 b$ & $11 a$ & $109 a$ & 1.550 \\
\hline N200 & & $3.5 c$ & $0.38 c$ & $41 a$ & $12 a$ & $109 a$ & $1.54 \mathrm{~b}$ \\
\hline N250 & & $3.6 b$ & $0.43 b$ & $43 a$ & $13 a$ & $109 a$ & $1.54 \mathrm{~b}$ \\
\hline N300 & & $3.8 a$ & $0.46 a$ & $45 a$ & $14 a$ & $109 a$ & $1.54 \mathrm{~b}$ \\
\hline \multicolumn{8}{|c|}{ Tillage $\times$ Nitrogen $(\mathrm{N})$ Interaction } \\
\hline \multirow[t]{4}{*}{ NT } & NO & 3.4 & 0.33 & 27 & 11 & 113 & 1.57 \\
\hline & N200 & 3.6 & 0.36 & 38 & 12 & 110 & 1.56 \\
\hline & N250 & 3.7 & 0.42 & 36 & 13 & 108 & 1.56 \\
\hline & N300 & 3.9 & 0.44 & 40 & 13 & 109 & 1.56 \\
\hline \multirow{4}{*}{ MT } & NO & 3.3 & 0.32 & 27 & 11 & 106 & 1.57 \\
\hline & N200 & 3.7 & 0.37 & 38 & 12 & 105 & 1.56 \\
\hline & N250 & 3.6 & 0.43 & 45 & 13 & 114 & 1.57 \\
\hline & N300 & 3.8 & 0.46 & 45 & 13 & 111 & 1.57 \\
\hline \multirow[t]{4}{*}{$\mathrm{CT}$} & No & 3.1 & 0.31 & 29 & 12 & 109 & 1.55 \\
\hline & N200 & 3.3 & 0.38 & 39 & 12 & 114 & 1.54 \\
\hline & N250 & 3.5 & 0.43 & 41 & 14 & 110 & 1.53 \\
\hline & N300 & 3.6 & 0.46 & 43 & 14 & 108 & 1.54 \\
\hline \multirow[t]{4}{*}{ DT } & No & 3.0 & 0.32 & 34 & 11 & 109 & 1.53 \\
\hline & N200 & 3.5 & 0.40 & 50 & 13 & 106 & 1.50 \\
\hline & N250 & 3.7 & 0.44 & 49 & 14 & 105 & 1.50 \\
\hline & N300 & 3.9 & 0.48 & 52 & 14 & 110 & 1.49 \\
\hline \multicolumn{8}{|l|}{$\mathrm{LSD}_{\mathrm{P} \leq 0.05}$} \\
\hline Tillage $\times$ Nitrogen & & 0.2 & ns & 4.0 & ns & 3.6 & 0.01 \\
\hline
\end{tabular}

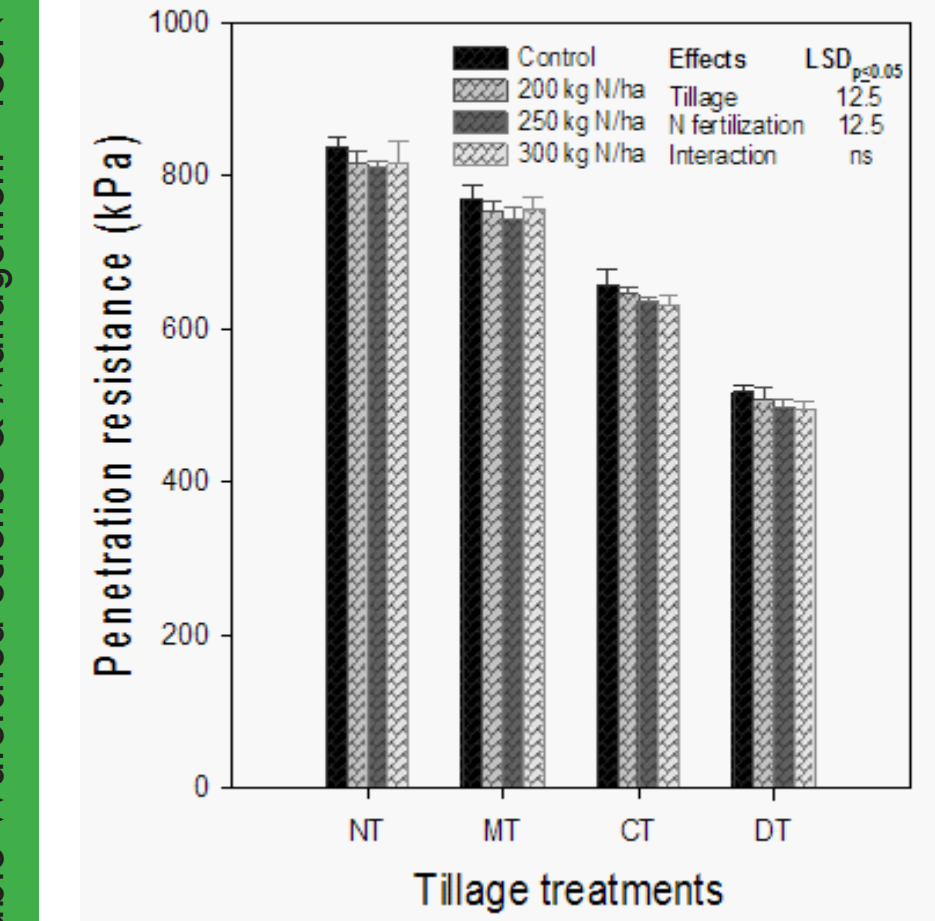

Figure 3. Tillage and nitrogen interaction on penetration resistance (strength) of soil [DT, deep tillage; CT, conventional tillage; MT, minimum tillage; and NT, no-till] under irrigated corn.

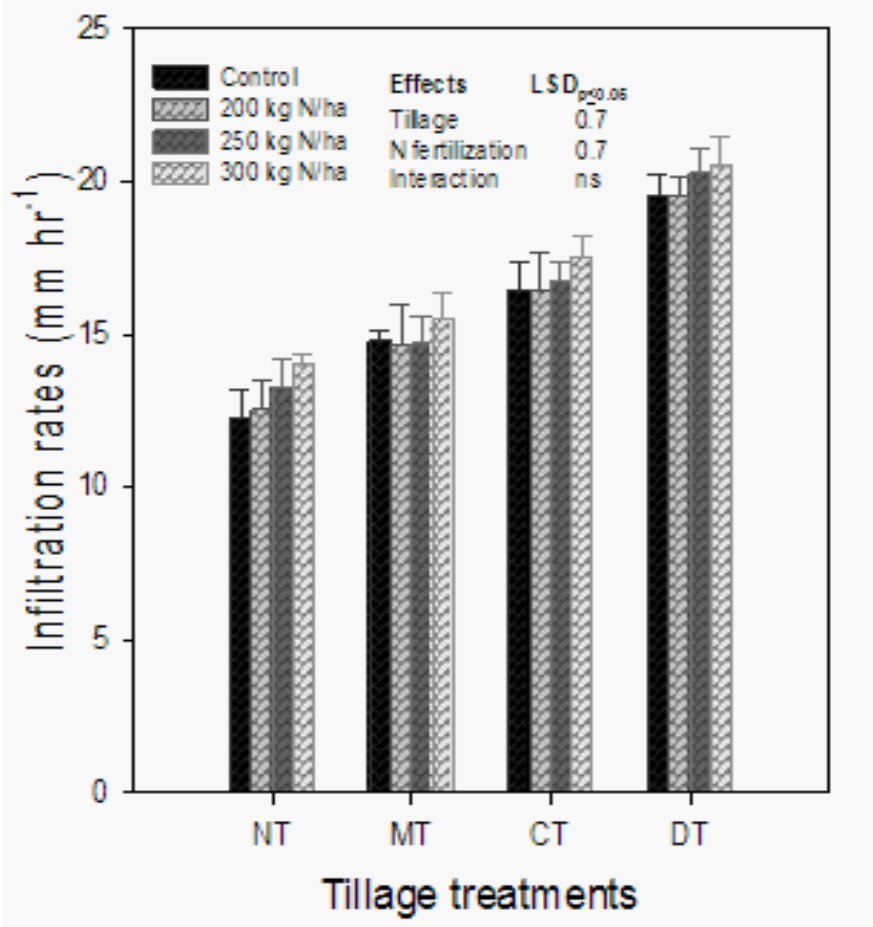

Figure 4. Tillage and nitrogen interaction on water infiltration characteristics of soil [DT, deep tillage; CT, conventional tillage; MT, minimum tillage; and NT, no-till] under irrigated corn. 
Table 2. Tillage and soil depth interaction on total carbon, total nitrogen, nitrate, available phosphorus and exchangeable potassium concentration and soil bulk density under irrigated corn.

\begin{tabular}{|c|c|c|c|c|c|c|c|}
\hline $\begin{array}{l}\text { Tillage } \\
\text { System }\end{array}$ & $\begin{array}{l}\text { Depth } \\
(\mathrm{cm})\end{array}$ & $\mathrm{C}_{\text {org }}$ & $\mathrm{TN}$ & $\mathrm{NO}_{3}$ & $\begin{array}{l}\mathrm{AP} \\
\mathrm{mg} \mathrm{kg}^{-1}\end{array}$ & $\mathrm{~K}$ & $\begin{array}{l}\rho b \\
\mathrm{~g} \mathrm{~cm}^{-3}\end{array}$ \\
\hline \multirow[t]{4}{*}{ NT } & 0 to 10 & 4.7 & 0.54 & 38 & 16 & 135 & 1.49 \\
\hline & 10 to 20 & 4.0 & 0.46 & 39 & 14 & 117 & 1.56 \\
\hline & 20 to 30 & 3.3 & 0.35 & 31 & 11 & 100 & 1.59 \\
\hline & 30 to 40 & 2.7 & 0.21 & 33 & 8 & 88 & 1.61 \\
\hline \multirow[t]{4}{*}{ MT } & 0 to 10 & 4.4 & 0.54 & 50 & 16 & 133 & 1.52 \\
\hline & 10 to 20 & 3.9 & 0.46 & 41 & 14 & 116 & 1.56 \\
\hline & 20 to 30 & 3.3 & 0.35 & 31 & 11 & 99 & 1.58 \\
\hline & 30 to 40 & 2.7 & 0.21 & 34 & 8 & 87 & 1.60 \\
\hline \multirow[t]{4}{*}{ CT } & 0 to 10 & 3.9 & 0.55 & 42 & 17 & 135 & 1.45 \\
\hline & 10 to 20 & 3.6 & 0.47 & 40 & 15 & 118 & 1.53 \\
\hline & 20 to 30 & 3.4 & 0.36 & 33 & 11 & 100 & 1.58 \\
\hline & 30 to 40 & 2.6 & 0.21 & 36 & 8 & 88 & 1.60 \\
\hline \multirow[t]{4}{*}{ DT } & 0 to 10 & 3.8 & 0.57 & 39 & 17 & 132 & 1.40 \\
\hline & 10 to 20 & 3.6 & 0.48 & 52 & 15 & 115 & 1.46 \\
\hline & 20 to 30 & 3.3 & 0.37 & 45 & 11 & 97 & 1.56 \\
\hline & 30 to 40 & 3.4 & 0.22 & 48 & 9 & 86 & 1.59 \\
\hline \multicolumn{8}{|c|}{$\operatorname{LSD}_{\mathrm{p}<0.05}$} \\
\hline \multicolumn{2}{|c|}{ Soil depth } & 0.1 & 0.01 & 1.8 & 0.5 & 1.7 & 0.02 \\
\hline \multicolumn{2}{|c|}{ Block } & ns & 0.01 & 1.6 & ns & 2.8 & ns \\
\hline \multicolumn{2}{|c|}{ Tillage $x$ soil depth } & 0.2 & ns & 4.0 & ns & ns & 0.04 \\
\hline \multicolumn{2}{|c|}{ Tillage $\times$ Block } & ns & 0.015 & ns & 0.7 & ns & ns \\
\hline
\end{tabular}

DT=Deep tillage, CT=Conventional tillage, MT=Minimum tillage, NT=No-till, $\mathrm{C}_{\text {org }}=$ Total carbon, TN=Total nitrogen, $\mathrm{NO}_{3}=$ Nitrate, $\mathrm{AP}=$ Available phosphorus, and $\mathrm{K}=$ Exchangeable potassium.

disperses soil aggregates, consequently, increased water infiltration rates.

\section{Total Carbon and Nitrogen, and Available Nutrients}

Tillage significantly influenced $C_{\text {org' }}, T N$, and nitrate contents except AP and K (Table 1). Averaged across depths, NT and MT had 6 to $9 \%$ more $C_{\text {org }}$ than in CT and DT. However, the $C_{\text {org }}$ content in NT, MT, and DT did not vary significantly. In contrast, TN was significantly higher $(\sim 5 \%)$ in DT higher than in NT and $M T$, respectively. Similarly, nitrate was higher in DT than in MT, $\mathrm{CT}$, and $\mathrm{ZT}$, respectively. Irrespective of tillage treatments, $\mathrm{C}_{\text {org' }}$ $T N$, nitrate, $A P$, and $K$ decreased significantly with increasing depths. However, $C_{\text {org }}$ and nitrate contents were significantly influenced by tillage $x$ depth interaction. NT and MT had greater $C_{\text {org }}$ at 0 to $10-\mathrm{cm}$ depth compared to DT and MT. Moreover, the depth distribution of $\mathrm{C}_{\text {org }}$ and nitrate under DT did not vary significantly compared to NT, CT, and MT, respectively. Nitrate was higher at 30 to $40 \mathrm{~cm}$ depth in DT than in CT, MT, and NT. The $\mathrm{C}_{\text {org }}$, TN, and nitrate contents were significantly influenced by $N$ levels except AP and $K$ (Table 1). The $C_{\text {org }}$ and TN contents increased progressively with higher $\mathrm{N}$ rates. While $\mathrm{C}_{\text {org }}$ increased by 1.2 to 1.5 times, TN increased by 1.7 to 2.6 times with increasing rates of $\mathrm{N}$ fertilization. Moreover, $\mathrm{N}$ fertilization results an increase in nitrate contents by 15 and $14 \%$ in N250 and N300 treatments compared to control. N level significantly influenced the depth distribution of $\mathrm{C}_{\text {org }}$ and nitrate contents.

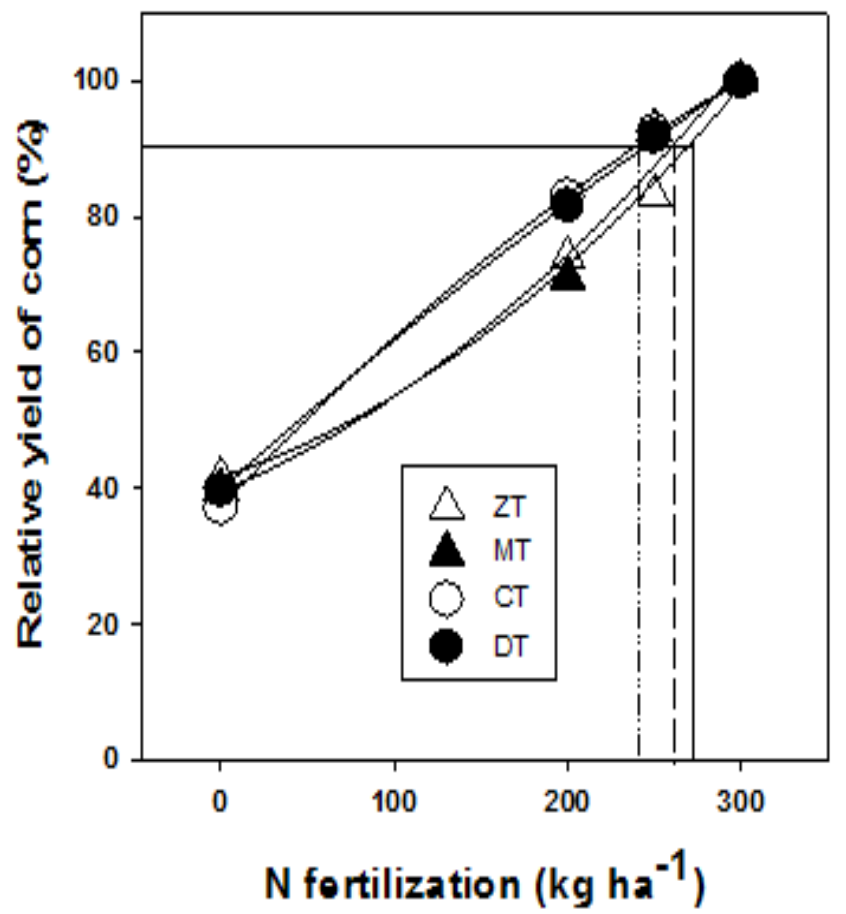

Figure 5. Tillage and nitrogen interaction on relative yield of irrigated corn [DT, deep tillage; CT, conventional tillage; MT, minimum tillage; and NT, no-till] (data combined over 2006 and 2007). 
Table 3. Nitrogen and soil depth interaction on total carbon, total nitrogen, nitrate, available phosphorus and exchangeable potassium concentration and soil bulk density under irrigated corn.

\begin{tabular}{|c|c|c|c|c|c|c|c|}
\hline $\begin{array}{l}\text { N rate } \\
\left(\mathrm{kg} \mathrm{ha}^{-1}\right)\end{array}$ & $\begin{array}{l}\text { Depth } \\
(\mathrm{cm})\end{array}$ & $\mathrm{C}_{\text {org }}$ & TN & $\mathrm{NO}_{3}$ & $\begin{array}{c}\mathrm{AP} \\
\mathrm{mg} \mathrm{kg}^{-1}\end{array}$ & $\mathrm{~K}$ & $\begin{array}{l}\mathrm{\rho b} \\
\mathrm{g} \mathrm{cm}^{-3}\end{array}$ \\
\hline \multirow[t]{4}{*}{$\overline{\mathrm{N}_{0}}$} & 0 to 10 & 3.3 & 0.44 & 28 & 14 & 134 & 1.48 \\
\hline & 10 to 20 & 3.3 & 0.38 & 28 & 13 & 116 & 1.53 \\
\hline & 20 to 30 & 3.3 & 0.29 & 29 & 10 & 99 & 1.59 \\
\hline & 30 to 40 & 2.9 & 0.17 & 31 & 7 & 87 & 1.61 \\
\hline \multirow[t]{4}{*}{$\mathrm{N}_{200}$} & 0 to 10 & 4.2 & 0.52 & 47 & 16 & 133 & 1.46 \\
\hline & 10 to 20 & 3.8 & 0.44 & 47 & 14 & 116 & 1.53 \\
\hline & 20 to 30 & 3.3 & 0.34 & 46 & 11 & 98 & 1.57 \\
\hline & 30 to 40 & 2.7 & 0.21 & 37 & 8 & 87 & 1.60 \\
\hline \multirow{4}{*}{$\mathrm{N}_{250}$} & 0 to 10 & 4.5 & 0.60 & 46 & 17 & 134 & 1.46 \\
\hline & 10 to 20 & 3.9 & 0.50 & 48 & 15 & 116 & 1.53 \\
\hline & 20 to 30 & 3.4 & 0.39 & 37 & 12 & 99 & 1.58 \\
\hline & 30 to 40 & 2.7 & 0.23 & 40 & 9 & 87 & 1.60 \\
\hline \multirow[t]{4}{*}{$\mathrm{N}_{300}$} & 0 to 10 & 4.8 & 0.64 & 49 & 18 & 134 & 1.46 \\
\hline & 10 to 20 & 4.1 & 0.54 & 49 & 16 & 116 & 1.53 \\
\hline & 20 to 30 & 3.3 & 0.42 & 40 & 12 & 98 & 1.57 \\
\hline & 30 to 40 & 2.9 & 0.25 & 42 & 9 & 87 & 1.60 \\
\hline \multicolumn{8}{|c|}{$\mathrm{LSD}_{\mathrm{p} \leq 0.05}$} \\
\hline \multirow{2}{*}{\multicolumn{2}{|c|}{$\begin{array}{l}\mathrm{N} \times \text { soil depth } \\
\mathrm{N} \times \text { Block }\end{array}$}} & 0.2 & ns & 4.0 & $\mathrm{~ns}$ & ns & 0.04 \\
\hline & & ns & 0.015 & ns & ns & 2.8 & ns \\
\hline
\end{tabular}

$\mathrm{DT}=$ Deep tillage, $\mathrm{CT}=$ Conventional tillage, MT=Minimum tillage, $\mathrm{NT}=$ No-till, $\mathrm{C}_{\mathrm{org}}=$ Total carbon, TN=Total nitrogen, $\mathrm{NO}_{3}=$ Nitrate, $\mathrm{AP}=$ Available phosphorus, and $\mathrm{K}=$ Exchangeable potassium.

Tillage and $\mathrm{N}$ level had significant interaction on $\mathrm{C}_{\text {org' }}, \mathrm{TN}$, nitrate, and $K$ contents (Table 1). $C_{\text {org }}$ was significantly higher in MT, NT, and DT with increasing levels of $\mathrm{N}$ fertilization as compared to CT. Similarly, TN increased with higher rates of $\mathrm{N}$ fertilization under $\mathrm{DT}$ than in other treatments. $\mathrm{N}$ fertilization increased nitrate content under DT as compared with CT, $M T$, and NT, respectively. Tillage and depth had significantly influenced TN, nitrate content and $\mathrm{K}$ (Table 2). The extent of all these parameters was in in order of 0-10>10-20>20-30> $30-40 \mathrm{~cm}$ depth.

Results on significant increase in $\mathrm{C}_{\text {org }}$ content are in consistent with the findings of other studies (Khurshid et al. 2006, Liebig et al., 2004), where $C_{\text {org }}$ content increased in NT surface than in DT and $\mathrm{CT}$. Greater $\mathrm{C}_{\text {org }}$ contents in 0 to $20 \mathrm{~cm}$ with NT may have resulted from slow crop residue decomposition due to the placement of crop residue on the soil surface and the decreased contact of crop residues with soil microorganisms (Salinas-Garcia et al., 1997), or can be attributed to the reduced mineralization of native soil organic matter (SOM) due to decreased soil aeration and temperature, greater of $C_{\text {org }}$ fractions within NT aggregates (Eghball et al., 1994). In contrast, greater incorporation of crop residues into the soil by plowing may have resulted in accelerated decomposition of crop residues, and thus decreased $C_{\text {org }}$ and TN contents. However, a higher $C_{\text {org }}$ content in DT at deeper depths than in other tillage treatments might be due to inversion of nutrient-rich topsoil and less exposure of the plant residues and native SOM to microbial decomposition. Similarly, a higher nitrate concentration at deeper depths of DT was probably due to leaching through changes in the soil structure and macrospores continuity (Golabi et al., 1995; Sadej and Przekwas,
2008). However, these results are in contradiction to Machraoui et al. (2010) who reported that tillage significantly improved K, $\mathrm{P}$ and $\mathrm{N}$ contents.

Significantly higher $\mathrm{C}_{\text {org }}$ content with increasing levels of $\mathrm{N}$ fertilization corresponds to the $C: N$ stoichiometry of soil organic matter. These results on increased $C_{\text {org }}$ content related to increasing $\mathrm{N}$ fertilization are in agreement with those reported by other studies (Pernes-Debuyser and Tessier, 2004, Liu et al., 2005, Blair et al., 2006). Increase in TN content with increasing $\mathrm{N}$ rates in the uppermost depth of has been reported (Sadej and Przekwas, 2008). Similarly, increasing levels of $N$ fertilization are associated with increased nitrate concentration. These results are in with those who reported that higher concentration of $\mathrm{C}_{\text {org }}, \mathrm{N}, \mathrm{P}$, and $\mathrm{K}$ was observed in higher levels of $\mathrm{N}$ fertilization compared to control treatment (Huang et al., 2010).

Greater $\mathrm{C}_{\text {org }}$ and TN under NT and MT with increasing levels of $\mathrm{N}$ fertilization may be associated with (i) higher biomass production, (ii) surface placement of crop residues, (iii) the lack of residue redistribution and disturbance, (iv) greater protection of crop residues and native SOM, and (v) undisturbed habitat for efficient biological activity (Eghball et al., 1994; Salinas-Garcia et al., 1997; Liu et al., 2005; Blair et al., 2006; Sundermeier et al., 2011).

\section{Corn Growth and Yield}

Tillage and $\mathrm{N}$ fertilization significantly influenced the corn plant height (Table 4). Maximum plant height $(206 \mathrm{~cm})$ was observed in DT followed by CT $(198 \mathrm{~cm})$ and minimum $(176 \mathrm{~cm})$ was recorded in NT. Overall, plant height was $18 \%$ higher in DT 
Table 4. Tillage and nitrogen interaction on plant height, grain and total yields, and harvest index of irrigated corn (data combined over 2006 and 2007).

\begin{tabular}{|c|c|c|c|c|c|c|}
\hline \multicolumn{2}{|l|}{$\begin{array}{l}\text { Treatment } \\
\text { Combinations }\end{array}$} & $\begin{array}{l}\text { Plant } \\
\text { ht. }(\mathrm{cm})\end{array}$ & $\begin{array}{l}\text { 1000-grain } \\
\text { weight (g) }\end{array}$ & Grain yield & $\begin{array}{l}\text { Total yield } \\
\left.a^{-1}\right)\end{array}$ & $\begin{array}{l}\mathrm{HI} \\
(\%)\end{array}$ \\
\hline \multicolumn{7}{|l|}{ Main plot: Tillage } \\
\hline \multicolumn{2}{|l|}{ NT } & $176 d^{\S}$ & $256 d$ & $5.7 d$ & $14.1 \mathrm{~d}$ & $41.1 \mathrm{~b}$ \\
\hline \multicolumn{2}{|l|}{ MT } & $190 c$ & $265 c$ & $6.3 c$ & $15.1 \mathrm{c}$ & $41.7 b$ \\
\hline \multicolumn{2}{|l|}{$\mathrm{CT}$} & $198 b$ & $295 b$ & $7.3 b$ & $15.8 b$ & $45.7 a$ \\
\hline \multicolumn{2}{|l|}{ DT } & $206 a$ & $305 a$ & $7.7 a$ & $16.8 a$ & $44.9 a$ \\
\hline \multicolumn{7}{|c|}{ Sub-plot: Nitrogen $\left(\mathrm{N}, \mathrm{kg} \mathrm{ha}^{-1}\right)$} \\
\hline \multicolumn{2}{|l|}{ NO } & $157 \mathrm{~d} \varphi$ & $194 d$ & $3.5 d$ & $8.4 d$ & $42.5 b$ \\
\hline \multicolumn{2}{|l|}{ N200 } & $177 c$ & $291 c$ & $6.9 c$ & $16.1 \mathrm{c}$ & $42.4 \mathrm{~b}$ \\
\hline \multicolumn{2}{|l|}{ N250 } & $204 b$ & $309 b$ & $7.9 \mathrm{~b}$ & $17.8 b$ & $44.4 a$ \\
\hline \multicolumn{2}{|l|}{ N300 } & $232 a$ & $327 a$ & $8.8 a$ & $19.5 \mathrm{a}$ & $45.0 a$ \\
\hline \multicolumn{7}{|c|}{ Tillage $\times$ Nitrogen $(\mathrm{N})$ Interaction } \\
\hline \multirow[t]{4}{*}{ NT } & NO & 138 & 171 & 3.2 & 7.1 & 44.6 \\
\hline & N200 & 165 & 261 & 5.7 & 14.2 & 40.0 \\
\hline & N250 & 186 & 287 & 6.4 & 16.6 & 38.4 \\
\hline & N300 & 214 & 304 & 7.7 & 18.6 & 41.4 \\
\hline \multirow[t]{4}{*}{ MT } & NO & 156 & 175 & 3.3 & 7.9 & 42.0 \\
\hline & N200 & 172 & 272 & 5.9 & 15.6 & 38.2 \\
\hline & N250 & 203 & 292 & 7.7 & 17.6 & 43.9 \\
\hline & N300 & 229 & 320 & 8.3 & 19.4 & 42.8 \\
\hline \multirow[t]{4}{*}{ Ст } & NO & 164 & 210 & 3.5 & 8.4 & 41.5 \\
\hline & N200 & 181 & 305 & 7.8 & 17.1 & 45.7 \\
\hline & N250 & 209 & 326 & 8.7 & 18.4 & 47.2 \\
\hline & N300 & 239 & 339 & 9.4 & 19.4 & 48.3 \\
\hline \multirow[t]{4}{*}{ DT } & NO & 169 & 222 & 3.9 & 10.3 & 38.0 \\
\hline & N200 & 192 & 323 & 8.0 & 17.5 & 45.8 \\
\hline & N250 & 220 & 332 & 9.0 & 18.6 & 48.2 \\
\hline & N300 & 244 & 344 & 9.8 & 20.6 & 47.6 \\
\hline \multicolumn{7}{|l|}{ LSD $p \leq 0.05$} \\
\hline \multicolumn{2}{|l|}{ Tillage $\times$ Nitrogen } & ns & & ns & & 2.0 \\
\hline
\end{tabular}

compared to NT. The DT had 19, 15, and 4\% more 1000-grain weight than NT, MT and CT, respectively. Grain yield was highest (7.7 $\mathrm{Mg} \mathrm{ha}^{-1}$ ) in DT followed by CT (7.3 $\left.\mathrm{Mg} \mathrm{ha}^{-1}\right)$ and NT had the lowest $\left(5.7 \mathrm{Mg} \mathrm{ha}^{-1}\right)$. The DT had $35 \%$ more grain production compared to NT. Maximum total yield $(16.8 \mathrm{Mg}$ $\mathrm{ha}^{-1}$ ) was attained in DT while lowest (14.1 $\mathrm{Mg} \mathrm{ha}^{-1}$ ) was in NT. The harvest index (HI) was significantly higher in CT than in DT and MT.

Nitrogen levels significantly influenced the growth and yield of irrigated corn (Table 4). Corn plant height was significantly higher by 13,31 and $48 \%$ in $\mathrm{N}_{200}, \mathrm{~N}_{250}$ and $\mathrm{N}_{300}$ compared to control. Similarly, $\mathrm{N}$ fertilization at 300,250 and $200 \mathrm{~kg} \mathrm{ha}^{-1}$ resulted in 68, 59 and $49 \%$ increase in 1000-grain weight compared to control. Increasing $\mathrm{N}$ levels out yielded grain yields by $2,2.3$, and 2.5 times compared with control. Total yields follows similar pattern in response to $\mathrm{N}$ fertilization. Tillage $\times \mathrm{N}$ fertilization interaction significantly increased the $\mathrm{HI}$ under DT and CT but decreased HI under NT and MT.

Significantly higher plant growth and yields are in conformity with other studies (Khan et al., 2001), who reported that corn plant height increased with DT and CT and decreased with MT and NT. Higher plant height and yield of corn under DT and CT may be attributed to reduced compaction, higher porosity, and more uniform distribution of nutrients in the soil profile. These results are also in agreement with those of Khan et al. (2001), who reported that annual plowing facilitates a favorable seedbed preparation to support for crop growth and nutrient-use. Rashidi and Keshavarzpour (2007) suggested that plowing produce a finer and loose soil structure, which in turn, positively influence the seedling emergence and establishment to support higher crop yields. Iragavarapu and Randall (1995) reported that moldboard plow produces higher yields than with NT. Mechanical difficulties affecting seed placement in addition to increased immobilization of $\mathrm{N}$ have often been considered responsible for the low crop yields with reduced and transitional NT compared to CT and DT (Lopez-Fando and Almendros, 1995).

A significant increase in plant height and crop yields of corn is attributed to the increased cell division and enlargement by $\mathrm{N}$ fertilization. Several studies have reported that $\mathrm{N}$ fertilization significantly increased plant height, grain yields, number of grains per cob, and grain weight per cob of corn plants (Prihar 
and Stewart, 1990; Shivay and Singh, 2000). A strong inference exists for $\mathrm{HI}$ to increase with increasing grain yield and decreasing crop stresses such as deficient nutrients and water (Prihar and Stewart, 1990). Balanced and adequate fertility ( 250 $\mathrm{kg} \mathrm{N} / \mathrm{ha}$ ) for any crop reduces stress, improves physiological resistance, and decreases disease risk (Krupinsky et al., 2002).

When plotted the relative corn yields over $\mathrm{N}$ fertilization levels, tillage showed variable but non-linear responses (Fig. 5). The extrapolation of the relationship suggested that $\mathrm{N}$ fertilization at $240 \mathrm{~kg} \mathrm{ha}^{-1}$ with DT and CT is required for near maximum production $(\sim 90 \%)$ of corn yields. In contrast, the relationship between $\mathrm{N}$ fertilization and relative yield showed that $90 \%$ of the corn yield was produced when $\mathrm{N}$ applied at $260 \mathrm{~kg} \mathrm{ha}^{-1}$ in MT and $270 \mathrm{~kg} \mathrm{ha}^{-1}$ in NT. Reduced rates of N fertilization (240 $\mathrm{kg} \mathrm{ha}^{-1}$ ) in DT and CT are probably due to higher background levels of available $\mathrm{N}$ from mineralization of native SOM and crop residues by annual and deep tilling the soil. $\mathrm{A}$ higher rate of $\mathrm{N}$ fertilization in transitional NT and MT is required to produce near maximum yields of corn ( $90 \%)$ was due to compaction and greater immobilization of available $\mathrm{N}$ under relatively undisturbed agro-ecosystems.

\section{Conclusions}

Tillage and nitrogen fertilization had variable effect on bulk density and soil strength, total carbon and nitrogen accumulation, nitrate content, and corn yields. Transitional deep tillage ( 2 years) decreased bulk density and soil strength, however, increased water infiltration than in no-till and minimum till, respectively. The effect of nitrogen fertilization on soil physical properties was less consistent than the effect of tillage treatments. Total carbon and nitrogen contents increased and nitrate content decreased in no-till and minimum till, respectively. Nitrate content was higher with increasing rates of $\mathrm{N}$ fertilization. Deep tillage had taller plants with significantly higher corn yields than in notill and minimum till, respectively. Similarly, nitrogen fertilization significantly increased corn yields and harvest index. Tillage and nitrogen interaction significantly influence total carbon and nitrogen, nitrate, and corn yields. While total carbon and nitrogen content increased by nitrogen fertilization under no-till and minimum till, nitrate content increased with nitrogen fertilization under deep tillage.

\section{References}

Bennie ATP and FJP Botha (1986) Effect of deep tillage and controlled traffic on root growth, water-use efficiency and yield of irrigated maize and wheat. Soil and Tillage Research 7(1-2): 85-95.

Blair N, RD Faulkner, AR Till, and PR Poulton (2006) Long-term management impacts on soil C, N and physical fertility: Part I: Broadbalk experiment. Soil and Tillage Research 91 (1-2): 30-38.

Eghball B, LN Mielke, DL McCallister, and JW Doran (1994) Distribution of organic carbon and inorganic nitrogen in a soil under various tillage and crop sequences. Journal of Soil Water Conservation 49(2): 201-205.

Golabi MH, E Radcliffe, WL Hargrove, and EW Tollerner (1995) Macropore effects in conventional tillage and no-tillage soils. Journal of Soil Water Conservation 50 (2): 205-210.
Habtegebrial K, BR Singh, and M Haile (2007) Impact of tillage and nitrogen fertilization on

yield, nitrogen use efficiency of tef Eragrostis, Trotter, and soil properties. Soil and Tillage Research 94(1): 55-63.

Huang S, WJ Zhang, XC Yu, and QR Huang (2010) Effects of long-term fertilization on corn productivity and its sustainability in an Ultisol of southern China. Agriculture Ecosystem and Environment 138(1-2) 44-50.

Iragavarapu TK and GW Randall (1995) Yield and nitrogen uptake of monocropped maize from a long-term tillage experiment on a poorly drained soil. Soil and Tillage Research 34(3): 145-156

Ishaq M, M Ibrahim, and R Lal (2002) Tillage effects on soil properties at different levels of fertilizer application in Punjab, Pakistan. Soil and Tillage Research 68(2): 93-99.

Islam KR. and RR Weil (2000) Soil quality indicator properties in midAtlantic soils as influenced by conservation management. Journal of Soil and Water Conservation 55(1):69-78.

Khan FUH, AR Tahir, and IJ Yule (2001) Intrinsic implication of different tillage practices on soil penetration resistance and crop growth. International Journal of Agriculture and Biology 3(1): 23-26.

Khurshid K, M lqbal, MS Arif, and A Nawaz (2006) Effect of tillage and mulch on soil physical properties and growth of maize. International Journal of Agriculture and Biology 8(5): 593-596.

Krupinsky JM, KL Bailey, MP McMullen, BD Gossen, and TK Turkington (2002) Managing plant disease risk in diversified cropping systems. Agronomy Journal 94(2): 198-209.

Lampurlanes,J, and C Cantero-Martinez (2003) Soil bulk density and penetration resistance under different tillage and crop management systems and their relationship with barley root growth. Agronomy Journal 95(3): 526-536.

Liebig MA, DL Tanaka, and BJ Wienhold (2004) Tillage and cropping effects on soil quality indicators in the northern Great Plains. Soil and Tillage Research 78(2)131-141.

Liu XB, JD Liu, BS Xing, SJ Herbert, K. Meng, X.Z Han, and XY Zhang (2005) Effects of long-term continuous cropping, tillage, and fertilization on soil organic carbon and nitrogen of black soils in China. Communication in Soil Science and Plant Analysis 36(9-10): 12291239

Lopez-Fando C and G Almendros (1995) Interactive effects of tillage and crop rotations on yield and chemical properties of soils in semiarid central Spain. Soil Tillage Research 36(1): 45-57.

Machraoui SBM, F Errouissi, M Ben-Hammouda, and S Nouira (2010) Comparative effects of conventional and no-tillage management on some soil properties under Mediterranean semi-arid conditions in northwestern Tunisia. Soil and Tillage Research 106(2): 247-253.

McGarry D, BJ Bridge, and BJ Radford (2000) Contrasting soil physical properties after zero and traditional tillage of an alluvial soil in the semi-arid subtropics. Soil and Tillage Research 53(2): 105-115.

Ogola JBO, TR Wheeler, and PM Harris (2002) Effects of nitrogen and irrigation on water use of maize crops. Field Crop Research 78123): 105-117.

Pernes-Debuyser A and D Tessier (2004) Soil physical properties affected by long-term fertilization. European Journal of Soil Science 55(3)505-512.

Pikul JJL and JK Aase (1999) Wheat response and residual soil properties following subsoiling of a sandy loam in eastern Montana. Soil and Tillage Research 51(1-2): 61-70.

Prihar SS and BA Stewart (1990) Using upper-bound slope through origin to estimate genetic harvest index. Agronomy Journal 82(6): $1160-1165$.

Rashidi M and F Keshavarzpour (2007) Effect of different tillage methods on grain yield and yield components of maize (Zea mays L.). International Journal of Agriculture and Biology 9(2): 274-277. 
Salinas-Garcia JR, JE Matocha, and FM Hons (1997) Long term tillage and nitrogen fertilization effects on soil properties of an Alfisol under dry land corn /cotton production. Soil and Tillage Research 42(1): 79-93.

SAS Institute. 2008. SAS online doc 9.13. SAS Institute, Inc., Cary, NC.

Sadej W and K Przekwas (2008) Fluctuations of nitrogen levels in soil profile under conditions of a long-term fertilization experiment. Plant and Soil Environment 54(5): 197-203.

Shivay YS and RP Singh (2000) Growth, yield attributes, yields and nitrogen uptake of maize (Zea mays L.) as influenced by cropping systems and nitrogen levels. Annals Agriculture Research 21(4): 494-498.

Sims JR and GD Jackson (1971) Rapid analysis of soil nitrate with chromotropic acid. Soil Science Society of America Proceedings 35(4): 603-606.

Sundermeier AP, KR Islam, Y, Raut RC Reeder, and WA Dick (2011) Not-ill impacts of soil biophysical carbon sequestration. Soil Science
Society of America Journal

75(5):1779-1788.

Unger PW and OR Jones (1998) Long term tillage and cropping systems affect bulk density and penetration resistance of soil cropped to dry land wheat and grain sorghum. Soil and Tillage Research 45(1): 39-57.

Varsa EC, SK Chong, JO Aboulaii, DA Farquhar, and FJ Olsen (1997) Effect of deep tillage on soil physical characteristics and corn (Zea mays L.) root growth and production. Soil and Tillage Research 43(3-4): 219-228.

Webb RA (1972) Use of boundary line technique in the analysis of biology data. Journal of Horticultural Sciences and Biotechnology 47(3):309-319.

Yang JY, EC Huffman, RD Jong, V Kirkwood, KB MacDonald, and CF Drury (2007) Residual soil nitrogen in soil landscapes of Canada as affected by land use practices and Agricultural policy scenarios. Land Use Policy 24(1): 89-99. 